\title{
The History of Somali Piracy: From Classical Piracy to Contemporary Piracy, c. 1801-2011
}

\section{Mohamed Haji Ingiriis}

\begin{abstract}
Sur la côte nord-est de la Somalie, la piraterie est un péril contemporain tant sur mer que sur terre. Le but de ce papier est de traiter la dimension historique de la piraterie somalienne, en particulier dans le Puntland, en employant des limites théoriques qui dépassent le champ de l'historiographie somalien actuel. Cette étude montre que la piraterie contemporaine garde un lien historique avec la piraterie classique, fait qui n'a pas été noté à ce jour, en partie à cause d'une focalisation sur la récente famine qui a dévasté la Corne de l'Afrique et qui semble fournir une explication immédiate. L'intention ici est d'ajouter un nouveau point de vue historique et dimension culturelle au discours actuel sur la piraterie en Somalie afin de la mettre en contexte. Utilisant la tradition orale et la documentation de voyages somaliens coloniales, cet article examine la piraterie somalienne dans un contexte global et somalien, en faisant valoir que les causes profondes de la piraterie dans cette partie de la Corne de l'Afrique ont été cultivés — non comme les chercheurs "nationalistes " ont soutenu-mais par la culture somalienne de vol de chameau, exacerbée par l'environnement hostile. Il est impossible, on fera également valoir, de comprendre la piraterie somalienne contemporaine sans plonger dans l'histoire maritime de la Somalie et la piraterie classique à terre. Ce document conclut que les pirates somaliens contemporains sont les descendants des pirates classiques qui étaient connus pour leurs déprédations dans la région du Cap Guardafui au cours du XIXe siècle. Enfin, ce document propose certains moyens pratiques pour entrevoir une fin à la piraterie.
\end{abstract}

\section{Introduction}

For many years, some piracy apologists have claimed that Somali piracy was an outraged response to illegal fishing on Somali shores and the outcome of the failed state syndrome. ${ }^{1}$ These arguments, prominent in media reports, were based on the premise that

1 See, for instance, Afyare Abdi Elmi, Understanding the Somalia Conflagration: Identity, Political Islam and Peacebuilding (London: Pluto Press, 2010), pp.9-11 and Abdi Ismail Samatar, Mark Lindberg \& Basil Mahayni, "The Dialects of Piracy in Somalia: the rich

The Northern Mariner/le marin du nord, XXIII No. 3, (July 2013), 239-266 
Somali piracy was a new phenomenon precipitated by grievances towards what pirate defenders termed "the other piracy," that is foreign, western fishing trawlers. Contrary to this perception, piracy was precipitated by the culture of looting rooted in Somali pastoralists' long-standing means for acquiring otherwise unobtainable cash and goods. This culture was partly created by impoverished conditions, massive unemployment, and lack of local opportunities for education or any other path to better living standards. Those who advocate for pirates depict them as erstwhile fishers involved in a campaign to cleanse the sea of illegal fishing, but pirates belie this view by pursuing life in an "epicurean manner."

The Roman legal philosopher Marcus Tullius Cicero described pirates two thousand years ago as "hostes humani generis" (enemy of all mankind). It was perhaps during this period when one Greek seafarer complained of extremely unruly Somalia residents after his crew were robbed in a coastal village surmised to be in the area now known as Puntland. ${ }^{2}$ The outrage of Cicero and the Greek seafarer would have received no currency among Somalis who likely regarded the pirates as local heroes. That attitude might be ascribed to a Somali pastoral tradition of camel raiding and plundering of other assets. Followers of I. M. Lewis, the doyen of English-speaking Somalists, would agree that he who robs the most is best respected in the pastoral Somali way of life.

To understand piracy off the northeast Somali coast today, one must delve into its historical roots. The socio-cultural and economic patterns of community interplay show that classical onshore piracy set the stage for contemporary offshore piracy. Contemporary pirates are the progeny of the classical pirates who were notorious for their depredations on the Cape Guardafui coast during the nineteenth century. Classical Somali piracy has not received the attention given to contemporary Somali piracy in the glare of publicity over attacks on merchant vessels carrying supplies for humanitarian aid intended for relief of the recent famine that devastated the Horn of Africa, especially Somalia.

Contemporary Somali pirates are mainly based in Puntland. Although there have been several incidents of proliferation of piracy to other areas in Somalia, ${ }^{3}$ classical piracy originally flourished in Puntland in the nineteenth century. Why was

versus the poor," Third World Quarterly vol. 31, no. 8 (2010), pp.1377-1394. For journalistic views that seek to justify the piracy see Najad Abdullahi, “"Toxic Waste' behind Somali Piracy," Al-Jazeera News English, 11 October 2008; Mohammed Adow, "The Pirate Kings of Puntland," ibid., 17 June 2009; Abdirahman Kulmiye, "Militia vs. Trawlers: Who is the Villain?," Africa Magazine, 9 July 2001; Saeed Shabaz, "Somali Piracy Connected to Toxic Dumping, Illegal Fishing," Final Call, 23 November 2008.

2 Anonymous, Periplus Maris Erythraei: The Periplus of the Erythrean Sea, translation, introduction and commentary by Lionel Casson (Princeton, NJ: Princeton University Press, 1989), p.155.

3 For a discussion on pirate activities in, broadly, southern Somalia, see Barney Jopson, "Somalia Bandits broaden their horizons off-shore," Financial Times, 19 November 2008; and Bilyana Tsvetkova, "Securitising Piracy off the Coast of Somalia," Central European Journal of International and Security Studies vol. 3, no. 1 (2009), p.48. 
that the case, and why, with the collapse of state institutions, has Puntland again emerged as the focal point of piracy? The pirate phenomenon warrants closer contextual and theoretical explanation; ${ }^{4}$ the present study argues that it can best be understood within the historical and socio-cultural framework of what François Simiand calls "histoire événementielle." Within this analytical structure the present paper employs a new approach, "absent presence," developed by Keith Jenkins to explore "a history of a certain kind," a type of longue durée. ${ }^{6}$ Excavating the truth, as Peter Hallward puts it, is "innovation en acte, singular in its location, but universal in its address and import."”

Using Somali oral tradition, nineteenth century accounts by British and other European visitors, and interviews with contemporary Somali officials, the study identifies the root causes of piracy in the Horn of Africa in the culture of Somali camel rustling, a method for gaining wealth in an always forbidding environment, lacking in both natural and man made resources. It does not refute the linkage between piracy, chronic poverty and illegal foreign fishing to which Somalia has lost millions of dollars. Rather, the purpose is to draw attention to the historical dimension of Somali piracy, particularly in Puntland, by employing a theoretical framework that transcends the scope of current Somali historiography to understand through the cultural context, especially the sub-culture of contemporary pirates. The intention is to add a new historical and cultural dimension to the current discourse on Somali piracy. The existing scholarship on Somali piracy is analysed and then conceptual clarification is suggested. The historical context in which the contemporary piracy was born and its causes and contemporary consequences are also explored, tracing the origins and early history of classical piracy to compare it to contemporary pirates. The study concludes by considering distinct, contrasting views on how to counter piracy.

4 Stig Jarle Hansen, "Modern Piracy as a Subject of Academic Enquiry," International Relations, 19 December 2008. There are numerous more recent works on Somali piracy, but focused either on security or on legal challenges. A few examples are: Christopher L. Daniels, Somali Piracy and Terrorism in the Horn of Africa (Plymouth, UK: Scarecrow Press, 2012); Bibi van Ginkel, The International Response to Somali Piracy: Challenges and Opportunities (Leiden: Brill, 2010); James Kraska, Contemporary Maritime Piracy: International Law, Strategy, and Diplomacy at Sea (Santa Barbara, CA: Praeger, 2011); and Peter Woodward, Crisis in the Horn of Africa: Politics, Piracy and the Threat of Terror (London: I.B. Tauris, 2012.)

5 Cited in Donald R. Kelley, "Review of John A. Marino, Early Modern History and the Social Sciences: Testing the Limits of Braudel's Mediterranean," Renaissance Quarterly vol. 57, no. 1 (2004), p.273; and Immanuel Wallerstein, Unthinking Social Science: The Limits of Nineteenth-Century Paradigms (Philadelphia, PA: Temple University Press, 2001), p.136.

$6 \quad$ Keith Jenkins, "Ethical Responsibility and the Historian: On the Possible End of a History of a Certain Kind," History and Theory: Studies in the Philosophy of History vol. 43 (December 2004), p.45. Jenkins sketches out a basic question which anchored on the theme of the issue entitled: "Do historians as historians have an ethical responsibility, and if so to whom and to what?"

$7 \quad$ Cited in ibid., p.46. 


\section{From Burton to Brichetti to Bahadur}

The scourge of piracy in the Somali littoral - and Puntland in particularrepresents today what Markus Rediker has shown elsewhere in a congruent context as "crime on a massive scale." 8 There are two broad dimensions, the impact that piracy has on Somalis, and the maritime security concerns of the international community. Contemporary piracy represents a great threat to the global economy, providing justification for western naval forces off the coast of Somalia to control the strategic basin of the Gulf of Aden. Virtually every nation in the world has been affected by Somali piratical predation. As James Kraska argues, "[e]ven those states that did not suffer a vessel hijacking paid more for oil, consumer goods and industrial products, as a result of increased insurance premiums and cargo risk 'surcharges' and the added cost of bypassing the Suez Canal and transiting around the Cape of Good Hope." In this context, Somali piracy remains sui generis in piracy scholarship compared to its counterparts in the world, primarily due to the pirates" "access to sanctuary" on the land, the local clanbased population that provides a permissive "hotspot" environment from which to launch their activities. Stopping piracy altogether at sea and on land raises several legal challenges, for using military force to counter this criminal clan enterprise has been contended to be itself a "criminal offence." "

It has been assumed that modern piracy emerged as a result of the chaotic anarchism which has engulfed Somalia since the late 1970s. ${ }^{11}$ In this respect, recent writings on Somali piracy are astoundingly ahistorical, with piracy scholars limiting themselves to the period since the collapse of Somalia's brutal military dictatorship in 1991. These studies offer none of the early historical background of piracy and thus failing - perhaps inadvertently - to put predation at sea into the Somali context, specifically its etymology in the nineteenth century piracy of shipwreck booty on the

8 Markus Rediker, Between the Devil and the Deep Blue Sea: Merchant Seamen, Pirates, and the Anglo-American Maritime World, 1700-1750 (New York: Cambridge University Press, 1987), p.255.

9 James Kraska, "Coalition Strategy and the Pirates of the Gulf of Aden and the Red Sea," Comparative Strategy vol. 28, no. 3 (2009), p.199.

10 For recent legal discourses on the Somali piracy, see M. D. Fink and R. J. Galvin, "Combating Pirates off the Coast of Somalia: Current Legal Challenges," Netherlands International Law Review vol. 56 (2009), pp.367-95; James Kraska and Brian Wilson, "Fighting Pirates: The Pen and The Sword," World Policy Journal (Winter 2008/09); J. Ashley Roach, "Countering Piracy off Somalia: International Law and International Institutions," The American Journal of International Law vol. 104, no. 3 (2010), pp.397-416; Ethan C. Stiles, "Reforming Current International Law to Combat Modern Sea Piracy," Suffolk Transnational Law Review vol. 27, no. 2 (2004), pp.299-326; and Craig Thedwall, "Choosing the Right Yardarm: Establishing an International Court for Piracy," Georgetown Journal of International Law vol. 41, no. 2 (2010), pp.501-23.

11 See David Blair, "Clan warfare splits Somalia; anarchy creates ideal conditions for piracy," Daily Telegraph, 22 November 2008; and Jeffrey Gentleman, "Somalia's Pirates Flourish in a Lawless Nation,” The New York Times, 31 October 2008, p.A1. 
coast of Cape Guardafui. Owing to this important gap, there appears to be an acute need for an historically informed explanation of the Somali concept of burcad-badeed (maritime bandits and sea robbers) in the coastal villages of what is now Puntland. In western and oriental chronicles, Puntland was referred to as either Northeast Somalia or Nugaal Valley; at other times, it was referred to by its clan name.

Three notable works that stand as exceptions to the lack of historical analysis are: Federico Battera, Dalla tribu allo Stato nella Somalia nord-orientale: il caso dei Sultanati di Hobiyo e Majerteen, 1880-1930; Robert L. Hess, Italian Colonialism in Somalia and Wayne K. Durrill, "Atrocious Misery: The African Origins of Famine in Northern Somalia, 1839-1884."12 However, these studies focus on specific historical occurrences. While Hess cursorily identifies the classical piracy and recognises the shipwreck looting as "pirate attacks on pearl fishers in the waters of British Socotra," offers no Braudelian description of either longue durée or événementielle.

J. Peter Pham's article "Putting Somali Piracy in Context" (2010) claims that historical looting of shipwrecks along the Puntland coast was "apparently induced by locals, representing a significant element in the [local clan] trading economy, organised by traditional leaders, and may even have contributed to centralising tendencies in the power structures of the local sultanates." ${ }^{14}$ Although the predation of ships and looting from shipwrecks in the area dates back through the nineteenth century, he otherwise overlooks the connection between contemporary pirates and those of the past. Pham nevertheless demonstrates that Somali piracy has always been a land-based crime, requiring a port from which to carry out its activities.

Kenneth Menkhaus argues that the nature of pirates has changed "from grievance to greed." 15 This argument reflects the oft-repeated claim that piracy is a response to illegal foreign fishing which has become a pretext to seize and loot ships and kidnap their

12 Federico Battera, Dalla tribu allo Stato nella Somalia nord-orientale: il caso dei Sultanati di Hobiyo e Majerteen, 1880-1930 (Trieste: Universita di Trieste, 2004); Robert L. Hess, Italian Colonialism in Somalia (Chicago \& London: The University of Chicago Press, 1966); and Wayne K. Durrill, "Atrocious Misery: The African Origins of Famine in Northern Somalia, 1839-1884," American Historical Review vol. 91 (1986), pp.287-306.

13 Hess, Italian Colonialism in Somalia, pp.127-28.

14 J. Peter Pham, "Putting Somali Piracy in Context," Journal of Contemporary African Studies vol. 28, no. 3 (2010), p.333 contends convincingly that local warlords, similar to those in the nineteenth century, profited from piracy, like "Colonel Abdullahi Yusuf who used his share of ransom money from the seizure of the Taiwanese trawler MV Shen Kno II in 1997 to embark on a political career that culminated in his disastrous tenure as "president of the [Transitional Federal Government] from 2004 to 2008." Pham quotes I. M. Lewis: "in so many facets of modern Somali life, there is much essential continuity between past and present." Similarly, Martin Murphy, Somalia, the New Barbary? Piracy and Islam in the Horn of Africa (London: C. Hurst \& Co., 2011), pp.44-58 accuses Yusuf of looting aid from refugees and of profiting from its subsequent resale, citing ICG report which had dubbed Yusuf as an "archetypal warlord." Murphy maintains that "[w]arlords do not generally allow profitable activities to operate on their territory without taking a cut." 
crews. David Blair's reporting and Joshua Ho's analysis agree that piracy began in Somalia in the 1980s. ${ }^{16}$ Pham maintains that the first incident of piracy recorded off the Somali coast was the seizure of the Jeddah-bound MV Naviluck and the killing of three Filipino crew members by Somali assailants off Haafuun on 12 January 1991. ${ }^{17}$ Contrary to these assertions, incidents of piracy off the coast of Somalia have a long, history, even if obscure because they had not yet been recorded comprehensively. Even the specialist on Somali piracy Stig Jarle Hansen, described by the University of Wales as "Professor among Pirates," claims that the "spatiotemporal and geographically constrained phenomenon" of piracy began in $1991 .{ }^{18}$ He convincingly suggests that Somalia as a whole cannot be regarded as pirate-infected: "only some regions host pirate ports." 19

The two most recent scholarly works about Somali piracy offer no new insights into its early historical background. Martin Murphy's Somalia, the New Barbary? Piracy and Islam in the Horn of Africa, a substantial work that includes 28 chapters and a conclusion, considers piracy as a new phenomenon beginning in 1989. Though full of academic references, it is also over reliant on media news reports, and provides no social history of piracy, other than recent ship hijacking incidents. While Murphy attemptssomewhat shrewdly - to equate contemporary Somali piracy with that of Berbers, he leaps into the Mediterranean piracy of the seventeenth century without noticing of the nineteenth century burcad-badeed in Puntland. Acknowledging that parallels are "pale at best," he analyses the British bombardment of Algiers in 1816, but fails to note a comparable British shelling of Puntland in 1802, in retaliation for the murder of British seafarers. ${ }^{20} \mathrm{He}$ argues that, similar to Barbary piracy, the "Somali piracy constitutes a significant part of society. It has a human and geographic hinterland. Like Barbary, it displays the features of a commercial system that shows signs of turning into a way of life." 21 He does not, however, present any evidence concerning the chronology of

16 Blair, "Clan warfare splits Somalia"; and Joshua Ho, "Piracy around the Horn of Africa," EchoGéo, no. 10 (2009).

17 Pham, "Putting Somali Piracy in Context," p.326.

18 Stig Jarle Hansen, Piracy in the Greater Gulf of Aden: Myths, Misconceptions and Remedies, NIBR Report (Oslo: Norwegian Institute for Urban and Regional Research, 2009), p.4.

19 Ibid., p.13.

20 See Martin Portenger, Narrative of the Sufferings and Adventures of Henderick Portenger (later modified into Narrative: Portenger's Shipwreck in the Red Sea (Bride-Court, Bridge Street: Sir Richard Philips and Co., 1819), p.25.

21 Murphy, Somalia, the New Barbary?, p.178. Murphy is not limited to the sphere of piracy. He attempts to explain the "rise and fall of the TNG [Transitional National Government] and the rise of TFG [Transitional Federal Government], as well as the 'growth of political Islam." For him, piracy has links with the failure of state institutions that has plagued Somalia over two decades, and crippled every attempt by the international community to rebuild order. He astutely observes that the United States' image among Somalis "was compromised by its association with [Mohamed Siad] Barre and various warlords over many years, and its more recently conducted air raids." (p.168). He might be right on that account. But due to the "mess of the Somalis own making" (p.164), he also suggests that a land campaign against piracy has to be avoided "at almost all cost" because of the possibility that 
piratical activities in the two regions to support the contention they had much in common.

In Deadly Waters: Inside the Hidden World of Somalia's Pirates, Jay Bahadur relates his personal experience in observing the Puntland pirates over a period of months. He had close contact with the highest echelons of the Puntland authority, and seems to accept uncritically most of their narratives concerning the interaction of pirates with society. ${ }^{22}$ Though he promises to uncover "the hidden world" of pirates, there is little beyond what has been circulated in the mainstream media for over twenty years. In contrast to Murphy, Bahadur is ready to concede that the "history of Somali piracy is still clouded in obscurity," ${ }^{23}$ yet likens Puntland piracy to the classic piracy depicted in Western storybooks. ${ }^{24}$ In parallel with Richard Burton who visited Somalia in 1854 and observed a country teeming with poets, ${ }^{25}$ Bahadur reports that "Puntland teems with pirates. ${ }^{26}$ Bahadur's observations follow a peculiar pattern. In the course of two visits to the area, he was a guest of Puntland "president" Abdirahman Farole. Bahadur's host Mohamed and translator Omar are Farole's sons, while his bodyguard, "Colonel" Omar Abdulahi Farole, is a nephew of Farole. ${ }^{27}$ Bahadur later realised that Colonel Farole was not a genuine colonel, but a local militiaman who promoted himself and was now waiting

any inhabitant in Puntland who owned a gun would come to the pirates' defence, as occurred in Mogadishu in 1993 during the "Black Hawk Down" fiasco, when Somalis resisted the attempts by the international community to reinstate law and order. Jay Bahadur, Deadly Waters: Inside The Hidden World of Somalia's Pirates (London: Profile Brooks, 2011).

23 Ibid., p.43.

24 Ibid., p.176.

25 Richard Burton, First Footsteps in East Africa (London: Longman, 1956). Burton visited north and west Somalia, while Brichetti visited from south to east and then to north. See his classical work, Lugi Robecchi-Bricchetti, Somalia e Benadir; viaggio de esplorazione nell'Africa Orientale (Milan: Carlo Aliprandi, 1899). The claim of the "first footsteps," seemingly suggesting that Burton was the first "white" traveller to visit the Somali interior, has been seriously questioned by some of the notable historians of the Horn of Africa. See Roy Bridges, "The Visit of Frederick Forbes the Somali Coast in 1833," The International Journal of African Historical Studies vol. 19, no. 4 (1986), pp.679-91; Harold G. Groves and Melvin E. Page, "John Studdy Leigh: First Footsteps in East Africa?," ibid. vol. 5, no. 3 (1972), pp.470-78; and James Kirkman, "John Studdy Leigh in Somalia," ibid. vol. 8, no. 3 (1975), pp.441-56.

27 Ibid., pp.98-99. Having resided in the "presidential" compound in Garowe, Bahadur seems unable to extricate himself from the Farole family, a trap into which certain unsuspecting researchers in Somalia had fallen before, becoming the intellectual hostages of their hosts. Rather than rigorously engaging with the enduring conundrums of piracy objectively, he follows the "advice" of one pirate who "admonished me to tell the story of him and his men exactly as they had given it to me" (p.107). That pirate insisted that "something good has to come back to us from all of this." On the other hand, Bahadur seems "struck by the chilling realisation that [he] had shared tea with murderers." In sum, critical examination shows that Bahadur is not oblivious to his consumption of pirate booty since the income of his host was based on it. 
for Farole to promote him to general. ${ }^{28}$ The family sought to win Bahadur's sympathy, and influence his research, particularly about how Puntland authorities deal with pirates. Bahadur had no inkling of what was really going on within this inner circle.

Bahadur and Murphy agree that the understanding of Somalia piracy would benefit from historical background, yet they offer nothing local, only a global-African, Arab and Islamic - context. These writers also agree that the broad concept of failed state should not be applied to all Somalia, but only to its southern portion. This effectively abandons the concept of a unified Somalia. If, for instance, the United States collapsed with Missouri and Maine enjoying relative peace, it would not mean that the two represented success, with the remainder of the country to be written off as a failed state. The future of a whole Somali country is at stake here and survival depends on how all people on board the ship are saved from the wreck.

\section{Theoretical and conceptual clarification: Let the pirates have their clothes}

The concept of piracy, as constructed through oral Somali literature and recent discourse, is not a new phenomenon in Somalia, where there are two terms long in use: burcad-badeed (sea robbers) or isbaarada badda (sea blockage). What is novel is armed sea robbers who venture deep into international waters, qowleysato (predatory buccaneers). The historical Puntland piracy was an onshore thuggery epitomised by an extreme Marxist doctrine: take the wealth from the wealthy by brute force and distribute it to the Dickensian population. On the other hand, contemporary piracy is an amalgam of onshore and offshore criminal enterprise based on a stock market. ${ }^{29}$

Somali society consists of pastoralists, farmers, fishers, urban-dwellers, and craftsmen. ${ }^{30}$ It is, however, dominated by nomadic pastoralists whose attitudes feature mutual suspicion compounded by extreme xenophobia. Charles Geshekter differentiates "nomads of the desert" from "nomads of the sea." 31 The ferocity of both forms of

28 Ibid., p.100.

29 Hansen, Piracy in the Greater Gulf of Aden, p.9, argues that "Puntlanders are less willing to work in the fishing industry since piracy seems to be more profitable."

30 See, for example, Ali Jimale Ahmed (ed.), The Invention of Somalia (Lawrenceville, NJ: Red Sea Press, 1995); Catherine Besteman, Unraveling Somalia: Race, Class, and the Legacy of Slavery (Philadelphia, USA: University of Pennsylvania Press, 1999); Catherine Besteman and Lee Cassanelli (eds.), The Struggle for Land in Southern Somalia: The War Behind the War (London: Haan Associates, 1996); Lee V. Cassanelli, The Shaping of Somali Society: Reconstructing the History of a Pastoral People, 1600-1900 (Philadelphia, USA: University of Pennsylvania Press, 1982); Abdi Kusow (ed.), Putting the Cart Before the Horse: Contested Nationalism and the Crisis of the Nation-State in Somalia (Trenton, NJ: The Red Sea Press, 2004); and Virginia Luling, Somali Sultanate: The Geledi City-State over 150 years (London: Haan Publishing, 2001).

31 Charles Geshekter, "Somali Maritime History and Regional Sub-Cultures: A Neglected Theme of the Somali Crisis," paper presented at the Australian Association for Maritime History and the International Commission of Maritime History, Fremantle, 6-10 December 1993, p.15. I am indebted to Professor Geshekter for sending me this paper. 
nomadic culture has made it hard for foreigners to safely enter and leave the Somali interior since colonial times. In the nineteenth century, one British authority on Somalia exclaimed that "to be killed was the fate of nearly every white man who ventured into the [Somali] country." 32 Nearly two hundred years later, this state of affairs still prevails. Kidnapping foreigners is now customary, leading one observer to generalise all Somalis by labelling them a "rapacious" society resistant to any rule. Embedded in pastoralist culture, which is the antithesis to that of farming and fishing, greed is associated with sharaf (respect), especially when one displays ambition to rob for the benefit of the clan members.

After more than fifty years of carefully studying each horizontal and vertical aspect of pastoralist Somali society through a longitudinal anthropological microscope, Ioan M. Lewis, often referred to the doyen of Somali studies, encapsulated his conclusions in the pages of the Sunday Times. The most important thing to understand about Somalis "is that they are not as other men ... they take orders from nobody ... their sense of independence is matched by a supremely uncentralised and fragmented degree of political organisation [which is] a kind of ordered anarchy." 33 Since Lewis concentrates most of his research on the northern Somali society, his conceptualization suffers from over-generalisation. Notable specialists have accused him of overemphasising a "primordial" theory and the importance of clan structure, "total genealogy," and "clan consensus" in Somali society. ${ }^{34}$ Lewis's arguments in fact echo those of the British colonial administrator F. M. Hunter, who in 1877 observed of the Somali community in Yemen:

They [Somalis] are a wild, high-spirited, yet timorous race, and in spite of the close contact into which they are brought with western civilisation, but seldom seem to profit by their experience. The men are little inclined for hard work, but they make excellent boatmen, carriage-drivers, cow-boys, punkah-pullers, etc. Every one who has visited Aden must be familiar with the half-naked, dark-coloured, well-built, and generally pleasant-feature savages, who, with hair stained yellow, rowed him ashore or drove him to visit the tanks, and the small boy of the same race has afforded him

32 F. L. James, The Unknown Horn of Africa: An Exploration From Berbera to the Leopard River (London: George Philip and Son, 1888), p.7.

33 Ioan Lewis, "In the land of the living dead," Sunday Times, 30 August 1992. By contrast, Lewis had written elsewhere that Somalis are intrinsically a democratic society. See I. M. Lewis, A Pastoral Democracy: a Study of Pastoralism and Politics among the Northern Somali of the Horn of Africa (London and New York: Oxford University Press, 1961), p.1.

34 See, for instance, Axmed Qassim Ali, "The Predicament of The Somali Studies" in Ali Jimale Ahmed (eds.) The Invention of Somalia (Lawrenceville, NJ: Red Sea Press, 1995), pp.71-80; Catherine Besteman, "Primordialist Blinders: A Reply to I. M. Lewis," Cultural Anthropology vol. 13, no. 1, (1999), pp.109-120; Lee Cassanelli, "Speculations on the Historical Origins of the "Total Somali Genealogy" in Markus V. Hoehne and Virginia Luling, Milk and Peace, Drought and War: Somali Culture, Society, and Politics, Essays in Honour of I. M. Lewis (London: Hurst, 2010), pp.53-66; and Lidwien Kapteijns, "I. M. Lewis and Somali Clanship: A Critique," Northeast African Studies vol. 11, no. 1 (20042010), p.1-24. 
an hour's amusement with his sportive tricks in the water and perpetual cry of "I dive, I dive." The women, on the contrary, are very industrious, and are seldom idle, employing themselves in weaving mats, and in their domestic concerns. ${ }^{35}$

Pirate activities are reinforced by a classless, egalitarian society that is correlated to the constant impulse to pursue maal (wealth) and xoolo (camels) on the part of the pastoralist culture. The demands of both compel the pastoralist to kill or be killed in what was considered in Somali oral tradition as ku dil ama ku dhimo (life and death adventure). In this mêlée, the pastoralist is prepared for death, as well as to rob, cheat, deceive and die in the bushes for personal greed. In the aftermath of a successful camel rustling and robbery, the pastoral nomads sing loudly xalaal iyo xaaraan, hadduu xera galo midna kuma xuma (no matter if you take camel either by lawful or unlawful manner; what matters most is to manage it to be your possession).

Pastoralist behaviour of life and death adventure precipitates a Darwinian environment where those who possess more firepower can dictate who rules Somalia. The pastoralist nomads seem to understand the illegitimacy of camel rustling in the saying that warns Hal xaaraan ah Nirig xalaal ah ma dhasho of which the English equivalent is "ill-gotten gains never prosper." The responsibility of clansmen in protecting pirates is compatible with the relationship between camel rustlers and clansmen that Ali Jimale Ahmed explains thus:

In the interior a camel is a source of prestige, power, greed, violence, wealth, theft, etc. The one who possess camels enjoys the respect of his clan. Like other sources of wealth and power, the camel owner's thirst for more is never assuaged. The greed lies not in the "source" of wealth, but in conditions of its ownership and in relations of producing it. Possessing a camel/camels does not, in itself, create the thirst for more. Greediness on the part of the camel owner is compounded and punctuated by the greediness of the camel rustler, who is another clansman and/or another owner of camels. For this reason, the camel owner needs the support and defense of his clansmen. A quasi-symbiotic relationship, which at times assumes a parasitic dimension, develops between the owner and the rest of the clansmen. To get the protection of his clansmen, the owner has to mitigate the needs of his kinsmen, in order to avert the forays of the camel rustler. The latter is determined to gain wealth in the quickest way possible. Towards this end he is willing to die. Even death accords him respect as he reaps great encomium for his bravery. ${ }^{36}$

35 See F. M. Hunter, An Account of the British Settlement of Aden in Arabia (London, Trübner, 1877, reprinted in 1968 by Cassol \& Co. Ltd), p.159.

36 Ali Jimale Ahmed, Daybreak is Near: Literature, Clans, and the Nation-State in Somalia (Lawrenceville, NJ: Red Sea Press, 1996), p.13. Said Samatar, who cited a poem composed by the "Mad Mullah," describing the camel as the "mother of man," has observed that "where some must survive by raiding, others must perish by being the object of the raid." $\mathrm{He}$ then asks himself a question that does not have a straightforward answer: "Does Somali culture in fact glorify pillage and bloodletting as overriding values?" Compare Said S. Samatar, "Somalia's Horse That Feeds His Master" in R. J. Hayward and I. M. Lewis (eds.), Voice and Power: The Culture of Language in North-East Africa. Essays in Honour of B. W. Andrzejewski (London, SOAS: 1996), p.159; and Said S. Samatar, Somalia: A Nation in 
Pastoral Somali culture and piracy are entwined. Piracy plays a central part in a pastoralist culture based on clan fraternity, which turns piracy into a clan-centred business, a continuation of pastoral business by other means. Pastoralists may be considered capitalists - business-oriented people insofar as they are "instinctively commercial and naturally pastoral and warlike." ${ }^{37}$ Piracy becomes a business, albeit a criminal one. Since Somalia was a terra incognita for both the East and the West, it is striking that the capitalist nature of Somali economic engagement with outsiders was reported by nearly every traveller who set foot in the country. Writing in 1892, G. D. Carleton commented that "[t]hese Bedouin [Somalis] are very business-like, and the first question, whenever asked to show lion tracks, is always, 'How much will you give?'."38

Somali oral tradition suggests that pastoralists first looted camels, and then much later moved on to plunder state institutions - why Somalia currently has the reputation of the world's most failed state- and then returned to shipwreck plundering, with onshore looting developing into global looting at sea. Many studies emphasize that Somali pirates "are becoming more desperate and the level of violence toward the crew[s of attacked vessels] has increased along with the number of crew injuries and hostages." 39 The intensificaiton of the struggle summons forth grim forbearance among the pirates, suggested in the Somali aphorism Allow waxba dhowran maynee, dhagaxyo soo daadi (O Allah, as we leave no stone unturned, may the sky rain more stones). They are sustained by social legitimacy within their communities that endow clan sanctuary. The culture of looting was expressed by one pirate who declared: "my life has changed dramatically ... it is incalculable how much money I have made ... I buy cars, weapons, and boats ... having a good time." ${ }^{40}$ This is what Murphy aptly termed "economic motivation for turmoil." ${ }^{41}$

Contemporary pirates, like those in the nineteenth century, are "disaffected youth from the large inland nomad population," ${ }^{42}$ who share their loot with clanspeople, clan chiefs, and, sometimes, with clan warlords. Pirates use clan customary law called Xeer in settling disputes and to govern themselves. Among pastoral Somalis, Islam is subordinate to clanism which shapes and defines everyday life. ${ }^{43}$ Pirates interviewed by Hansen

Turmoil (London: Minority Rights Group Report, 1991), p.9.

James, The Unknown Horn of Africa, p.2.

G. D. Carleton, "Notes on a Part of the Somali Country," Journal of the Anthropological Institute of Great Britain and Ireland vol. 21 (1892), p.170. Carleton relates that a "common occurrence" was hearing of "camels being stolen, killed and eaten on the spot by thieves," thus "camel's flesh [was] much loved" by the Somalis who also had great faith in camel's milk "as a cure."

Freedom C. Onuoha, "Piracy and Maritime Security off the Horn of Africa: Connections, Causes and Concerns," African Security vol. 3, no 4 (2010), pp.194-95.

Thean Potgieter and Clive Schofield, "Poverty, Poaching and Pirates: Geopolitical Instability and Maritime Insecurity off the Horn of Africa," Journal of the Indian Ocean Region vol. 6, no. 1 (2010), p.97.

Murphy, Somalia, the New Barbary?, p.51.

Bahadur, The Pirates of Somalia, p.241.

For authoritative and informative analyses on the importance of clan and clanism within 
acknowledged that their clans gave them protection and a moral support so strong that clansmen prayed for their safe return. One pirate stated the societal custom thus: "[w]hen you capture a ship [clansmen] welcome you like you are a president. Piracy is something that is bad now and in hereafter, and people know that and I know that, but some people just respect you and welcome you per se but they also pray for you." ${ }^{44}$

The definition of piracy by the International Maritime Bureau (hereafter IMB), an "act of boarding or attempting to board any ship with the apparent intent to commit theft or any other crime and with the apparent intent or capability to use force in the furtherance of that act, ${ }^{, 45}$ does not differentiate armed robbery from piracy. Thus the Somali shipwreck robberies in the nineteenth century, in which the looters were armed with bows and arrows, falls into the piracy category. Indeed Charles Davies's study of Arab depredations in the late eighteen and early nineteenth centuries has demonstrated that "piracy is only a sea term for robbery." ${ }^{46}$ That analysis fits the facts of both classical and contemporary Somali piracy better than Eric Hobswawm's characterization of piracy as a "universal and virtually unchanging phenomenon, [an] endemic protest against poverty: a cry for vengeance on the rich." ${ }^{\prime 7}$

\section{Classical onshore piracy}

Somalia has littoral links to the Red Sea, Gulf of Aden, and Indian Ocean, and thence to the Mediterranean Sea, the Suez Canal and as far away as the coast of South Africa. Long before European colonialism at the end of nineteenth century, looting of shipwrecks was pervasive in Puntland. Then, as now, the sea route off the Somali coast was important to to world commerce, connecting the West to the East. ${ }^{48}$ During the early

Somali society, see Ahmed, Daybreak is Near; Christian Bader, Le Sang et le sait: Brève histoire des clans Somali (Paris: Maisonneuve et Larose, 1999); Abdalla Omar Mansur, "The Nature of the Somali Clan System," in Ali Jimale Ahmed (ed.), The Invention of Somalia (Lawrenceville, NJ: Red Sea Press, 1995); and Conflict in Somalia: Drivers and Dynamics (Washington: World Bank, 2005).

44 Hansen, Piracy in the Greater Gulf, p.40.

45 International Maritime Bureau (IMB), Piracy and Armed Robbery against Ships: A Special Report (London: International Chamber of Commerce, 1997), p.2.

46 Charles E. Davies, Blood-Red Arab Flag: An Investigation Into Qasimi Piracy 1797-1820 (Exeter: University of Exeter Press, 1997), p.66.

47 Eric Hobswawm, Primitive Rebels: Studies in Archaic Forms of Social Movements in the $19^{\text {th }}$ and 20 $0^{\text {th }}$ Centuries (New York: Norton, 1959), cited in Rediker, Between the Devil and the Deep Blue Sea, p.269. For Somali context, see "Somali Pirates Good at Western Propaganda," Somaliland Times, issue 396, 29 August 2009; and United Nations World Food Program, "Somalia Piracy Threatens UN Lifeline to Country," 10 July 2007.

48 See Davies, Blood-Red Arab Flag, p.170; George E. Brooks and Norman Bennet (eds.), New England Merchants in Africa: A History through Documents, 1802 to 1865 (Brookline: Boston University Press, 1965); and C. G. Brouwer, "Non-Western Shipping Movements in the Red Sea and Gulf of Aden during the 2nd and 3rd Decades of the 17th Century, according to the Records of the Dutch East India Company (part 2)" in Die Welt des Islam, New Series, bd. 32, no. 1 (1992), 7, 10, 15, 16, 27, 29 and 33. 
eighteenth century piracy was common on the African shores of the Indian Ocean basin, ${ }^{49}$ as well as in the Gulf of Aden and Red Sea. Some Arab tribes in present-day United Arab Emirates (UAE) were notorious for brutal activities at this time, plundering a "number of dhows and boats bringing supplies from Berbera and Zeila" in northern Somalia to Yemen. Charles Davies notes that Qasimi pirates raided and destroyed the Berbera port in $1819 .^{50}$

Somali shipwreck plundering can be considered an emulation of Qasimi piracy that inspired some Somali coastal villagers to seek their share of booty. It may not be a coincidence that Boosaaso, the largest - and by far the most important - town in Puntland at present, was previously known as Bandar Qasim., ${ }^{51}$ a name given by the Arabs. ${ }^{52}$ The Qasimi pirates operated from Socotra, ${ }^{53}$ adjacent to Puntland, and Bandar Qasim may have been another of their bases. In 1854, Charles Guillain, a French explorer who was sent to pave the way for a future French colony on the coast of East Africa, called Bandar Qasim the "most important village" of northeast Somalia. ${ }^{54}$

Even though there is no evidence that any Somali vessel participated in the Qasimi piracy, as late as the nineteenth century vessels from Ras Al Kheymah in UAE were frequent visitors in Yemen and to the Somali coast. ${ }^{55}$ A treaty between the rulers of the south Yemeni coast and the northeast Somali coast was signed in Mukallah on 9 December 1875, which "concluded among themselves obligations, agreements and bonds, to the effect that their condition should be one, and their port cities should be as one." 56

In the early 1880 s, Langton Walsh noted in his diary that northern Somalia had hosted "descendants of the pirates settled at Zanzibar and Muscat." 57 Both coasts were ruled by interventionist Arab rulers who had direct access to, and at times hegemony over, Somali coasts. The classical Somali pirates appear to have been stirred by the proliferation of the Arabian piracy under the pretext of resisting "Christian infidels." A striking feature is that the Somali pastoralist culture was generally influenced by ancient pastoral Arab culture in such a way that they often went hand in hand. For example, the

49 Rediker, Between the Devil and the Deep Blue Sea, p.257.

50 See Davies, Blood-Red Arab Flag, p.209, 316 and pp.319-20.

51 Bandar is a Persian word meaning port. Although the name of Somali capital, Mogadishu, derives from a Persian word meaning "the seat of the king", the city used to have another Persian name, Benadir, which might be the plural of Bandar.

52 Giulio Baldacci, "The Promontory of Cape Guardafui," Journal of the Royal African Society vol. 9, no. 33 (1909), p.60.

53 Davies, Blood-Red Arab Flag, p.89.

54 Charles Guillain, Documents sur l'histoire, la geographie et le commerce de l'Afrique Orientale (Paris 1856-1857), p.407, cited in Durrill, « Atrocious Misery, » p.299.

55 See R. J. Gavin, Aden under British Rule (London: C. Hurst \& Co., 1975), p.52.

56 Lidwien Kapteijns and Jay Spaulding, "Indian Ocean Diplomacy: Two Documents Relating to the Nineteenth Century Mijertein Coast," Sudanic Africa vol. 13 (2002), p.25.

57 Langton Prendergast Walsh, Under the Flag and Somali Coast Stories (London: Andrew Melrose, 1910), p.237. 
social ways of the clanship system in most Somali communities were derived from ancient Arabian culture; the Somali term for clan, qabiil, is the Arab word. ${ }^{58}$ Several northern clan chiefs, upon seeing Arab clan hierarchy, promptly declared clan kingdoms in the early nineteenth century in northwest and northeast Somalia, adjacent to the Arab peninsula. Nearly every sub-clan claimed to be a direct descendant of an Arabian household. ${ }^{59}$

Islam was another fundamental link between the Somalis and the Arabs. "Prior to the end of the nineteenth century, Somali religious practitioners looked almost exclusively to Arabia as the primary source of religious learning."

While northern Somalis are closer to Arabia where the claim of Arab ancestry achieved an unrivalled currency, the Arab influence was more visible in the southern Somalia than in the northern part. ${ }^{61}$ The ethos of the Somali pastoralists is tantamount to the description of Arab society observed by one British explorer: "Every man has a slavish obedience to the [chief of the clan], yet is as free in his mind as the air he roves through, he is as wild as the deserts and hills he travels over, and as high spirited as the [camel] he rides." ${ }^{, 2}$

The distinction between Somalis and Arabs appears to be sea fishing, which is a cursed career among Somali pastoralists who loath fish, indeed fear anything connected with what they consider bad iyo belaayadeeda (sea, as well as its magic and mystery). Yet they do not mind if the sea provides them with qaniimadii badda (sea booty). ${ }^{63}$ Geshekter explains:

Somalis consider the sea as a barrier and a bridge. Given their cultural abhorrence of fish consumption, few Somalis relied on fishing for a livelihood although the Somali language refers specifically to the sea and to those who live across it. When nomads refer to people who have gone to live abroad they say badduu tegay ("they have gone to the sea"). The word maax refers to water that seeps into the bottom of a freshly dug well in a pastoralist area while badmaax means a seaman. Children used to be named Badmaax by parents who understood the richness of the sea, although this

58 The Somali language is Cushitic - one of the five branches of the Afroasiatic family of languages and would not be understood by an Arab speaker.

59 It has often been stressed that the "Somalis have a tradition that their ancestors emigrated from the Arabian province of Hadramut" in Yemen. See C. P. Rigby, "On the Origin of the Somali Race, Which Inhabits the North-Eastern Portion of Africa," Transactions of the Ethological Society of London vol. 5 (1867), p.93.

60 Scott Reese, Renewers of the Age: Holy Men and Social Discourse in Colonial Benaadir (Leiden: Brill, 2008), p.6.

61 See Mohamed Haji Mukhtar, "Islam in Somali History: Fact and Fiction," in Ali Jimale Ahmed (ed.), The Invention of Somalia (Lawrenceville, NJ: Red Sea Press, 1995).

62 Captain Francis Erskine Loch, "Diaries of Captain F. E. Loch, Compiled by him in 1835," Scottish Record Office, Edinburgh, GD1/633/1\&2, p.236.

63 Geshekter, "Somali Maritime History," p.6. 
would not generally be a nomad. ${ }^{64}$

Geshekter's observation is captured by a popular poem in which a Somali man named Badmaax - meaning seafarer - was obligated by the family of his lover for "a high brideprice." Badmaax travels to India by sea to work there and come back with wealth to marry her. Unfortunately, on his return voyage the ship is wrecked. He sings:

Anba waan jeclaa
Inaan soo dhakhsado
Jilaashihii baa
Jidka igu xannibay
I am longing to return
But the southwest monsoon winds
Battered me on the way,
And keep me from coming back.
The lover replies:
Dooniyihii Suur iyo
Reer Saaxil yimide,
Doonyihii Bombay
Ma Bir baa ka jaban?
The ships from Oman
And from East Africa have arrived
But the ships that were to come from Bombay
Is there some broken iron on them [what happened to them?] ${ }^{65}$

While oral histories like these suggest dependence on the sea, one British officer, who spoke of the "murderous, unyielding Somali deserts, the absolute zero of wilderness," observed that a Somali nomad pastoralist (whom he labelled a "savage") 66 was astounded when he set eyes on the sea for the first time. Gerald Hanley, in Warriors: Life and Death among the Somalis, remarked:

When Mohamed got down off his truck he was paralysed, rooted there in the sand and trembling from head to foot as he watched and listened to the great tumult of the ocean rolling to him. He had never visualised anything like it and he could not speak. Even the askaris [local soldiers] were silent as they watched him study it all with his rolling, worried eyes [...] For me it was one of the strangest experiences I have ever had, seeing a desert savage shivering in front of the ocean for the first time, as if expecting the ground to melt and swallow him up at any moment. We must all have been like that once, in a time of thunder or storm, a million years ago in innocence. ${ }^{67}$

64 Ibid., p.12.

65 Ibid., pp.12-13.

66 The eminent expert on the Somali history, Lee Cassanelli, explains that this term was frequently employed, reflecting "European prejudices of the era," to refer to rural Somalis. See Lee V. Cassanelli, "Tradition to text: writing local Somali history in the travel narrative of Charles Guillain (1846-48)," Journal of African Cultural Studies vol. 18, no. 1 (June 2006), p.60. In 1888, a British traveller had described the Somalis as "semi-civilised." See James, The Unknown Horn of Africa, p.vii.

67 Gerald Hanley, Warriors: Life and Death among the Somalis (London: Eland, 1993), quoted 


\section{"Hannibal Lecters"}

The first recorded incident of classical piracy in Somalia occurred in the "God forgotten place" over two centuries ago. One evening on 7 June 1801, the British ship Weisshelm, sailing from India to Egypt, wrecked on the coast near the impoverished village of Haafuun in present-day Puntland, close to Eyl which is the town now known as "the pirate capital of Puntland." Of the twenty passengers, six perished on the spot. Others held fast to the "piece of wreck which they had seized when quitting the ship," but one of them died as soon as they reached shore. The survivors, weak as they were, managed to bury the bodies of their unfortunate fellows, but soon were surrounded by twenty Somali warriors. Some were armed with:

matchlocks and some with bows and arrows, but all carried a large knife like a sabre and pike. The Africans stripped the castaways of their clothing and other possessions. They also removed silver bracelets from the officers' Indian servants by first cutting off their arms. Toward sunset, a local [clan] chief approached the beach with more [warriors]. He spoke awhile with his men, then formed them into a line, and ordered the warriors to brandish their weapons at the Europeans as if they were going to kill them. The Weisshelm's survivors made a dash for some nearby hills. Those who could not run fast enough, or were wounded by the Africans' shots, were immediately butchered as soon as overtaken. Those who escaped were rescued [nearly five months later] by a British brig-of-war that became becalmed close to the Somali shore... Their experience was not unique. They ran afoul of the [Somalis], a group infamous among European sailors for their fearsome treatment of castaways. ${ }^{68}$

Henderick Portenger, one of the survivors, recorded the details of the initial attacks. As the captain tried to defend himself, one of the warriors:

laid him senseless at his feet, by a blow on the head with a stick, and they would have cut him to pieces we had not ourselves, in the greatest hurry, undressed him and delivered his clothes to them. Far more cruel and ferocious was the treatment a few unfortunate Hindu servants to the officers received from these bloody monsters; they happened to have on their arms some silver bracelets; in their eagerness to seize this glittering prey, they did not take the trouble to take off the bracelets, but cut off the poor fellows' arms with their long knives, to get at them the quicker. They treated, however, the Lascars, or Hindu sailors of the ship, with a little more lenity than they did [to] us [...] Some of the sailors having made us of liquor, before the arrival of these savages [sic], got immoderately drunk, and were lying asleep among the casks, where the savages [sic] murdered them as soon as they discovered them. As yet they had spared the lives of those among us who were sober; but, not withstanding, our situation was worse than death, and we envied those who had been murdered. ${ }^{69}$

in Gentleman, "The Pirates Are Winning," p.2. It is apparent that Somalis, argues Geshekter, "might change locales but they never left their cultural background either in their mind or in their behavior," showing that there is no Somali term for "exile". Geshekter, "Somali Maritime History," p.15.

68 Durrill, “Atrocious Misery,” pp.287.

69 Portenger, Narrative of the Sufferings, p.6. Lascars is an Urdu term meaning army. It referred 
In the course of several weeks that they were hiding in the hills of Puntland, the survivors' number was reduced to five; the rest were parted from them during a "fatiguing march" on a dark night—-most likely they died of hunger and thirst. Soon fate overcame their "beloved" captain:

[O]ur poor captain sat himself down on the ground, declaring he was incapable of proceeding any further, requesting we would leave him and go on, as he was determined to stay there and die, but we declared we would not abandon him, and if he was determined to stay, so would we. We persuaded him, with some difficulty, to try to go on with us again. Two of us took him under the arms to support him and help him on, but we were soon obliged to give it up, as he did nothing but lament and cry bitterly, begging us, for God's sake, to lay him on the ground, and let him die quietly. We were, at last, obliged to comply with his desire; he, therefore, laid himself down again, and we sat down by his side. He requested us again to leave him to his fate; that he must die; that he was convinced there were savages [sic] in the neighbourhood, and that it was better that one should die alone, than all perish. He begged of us, however, most fervently, that if any of us should have the happiness to find our way into a civilised country, not to forget to publish his death, and more particularly to acquaint his brother how and where he had ended his life, telling us at the same time that his brother was a colonel at Madras, and bore the same name with himself namely, Baer. We promised him everything. We should not, however, have abandoned him; but all at once we heard the cries of some savages [sic], and saw about thirty of them, who were running towards us. No time was to be lost. We four, that is, St Julien, Beck, Voss, and myself, ran as fast as our legs would carry us, and again had the good fortune to escape our enemies before they perceived us, but the unfortunate captain remained behind. We soon heard their noise drawing towards the spot where we had left him. Heaven only knows what was his fate: whether these monsters killed him or not. ${ }^{70}$

Another two survivors succumbed to starvation, thirst and exhaustion, leaving only Portenger and St Julien.

The only method open to them to survive was to claim to be Muslims from Arab peninsula as they moved from one village to another, scrounging scraps of food. In one village, where they were reasonably well received, they did not succeed in their ruse and came under pressure to convert to Islam; Portenger insisted in his published account that $^{71}$ they refused to do so. Portenger and St. Julien were finally saved by a British

to East Indian sailors and British army servants hailing from Southeast Asia who were regarded as "unfree labour" during voyages. As Janet J. Ewald reminds us, "British ships became probably the largest employers of Indian ocean sailors, whom they called lascars." Janet J. Ewald, "Crossers of the Sea: Slaves, Freedmen, and other Migrants in the Northwestern Indian Ocean, c. 1750-1914," The American Historical Review vol. 105, no. 1 (2000), p.75. On being Lascar, see Michael H. Fisher, "Working across the Seas: Indian Maritime Labourers in India, Britain, and in Between, 1600-1857," International Review of Social History vol. 51 (2006), pp.21-45.

70 Portenger, Narrative of the Sufferings, pp.10-11.

71 Whereas the classic Somali pirates forced Portenger's survivors to convert to Islam, the 
warship that fortunately was becalmed close enough to the Puntland shore that the crew could see their frantic gestures. The warship put ashore a water party, which was attacked by the natives, who persisted even after the British seamen fired a musket volley, and the landing party suffered casualties, including the unfortunate St. Julien, killed just after his deliverance from the months-long ordeal. The warship bombarded a nearby village in retaliation. Portenger observed that "for what was not destroyed by the guns was consumed by the fire, so that nothing remained of the whole village but a heap of ruins." 72

Even though Portenger's account does not mention the village by name, he seems to refer to Haafuun. ${ }^{73}$ In 1846, Charles Cruttenden, a British colonial official assessing the area, found Haafuun "a few miserable Somali huts, and a population of perhaps 50 people, who offered ivory, ostrich feathers, ambergris, and fish-teeth for sale." ${ }^{\text {,74 }}$

\section{Shipwreck booty business as a source of income}

Despite this early retribution, the frequent shipwrecks on the Puntland coast caused plundering to be the rule of the day, transforming the consciousness of the local population. Strong currents "swept northward in July and August at seven to eight knots off the Somali south coast," Haafuun and Alula to the point of the Horn." C. G. Brouwer observes that weather patterns in fact made the region potentially treacherous through much of the year. The north-east monsoon blew over the coast "from mid-October through March, the southwest monsoon from May through September.",76

Growing international rivalry and trade in the area during the first half of the nineteenth century brought a corresponding increase in marine traffic — and wrecks. This ushered in a new era in the history of piracy in Somalia, marked with anarchy and rivalry

contemporary pirates do not compel it. Natalie Zemon Davis, Trickster Travels: A SixteenthCentury Muslim Between Worlds (New York: Hill \& Wang, 2006), describes the story of a $16^{\text {th }}$ century Muslim man called Hassan Al Wazzan who was forced to convert to Christianity after being kidnapped by Christian pirates from the Moroccan littoral.

72 Portenger, Narrative of the Sufferings, p.25.

73 Interview with General Osman Haji Omar "Falco," the former Police commissioner of Bari region, London, UK, 7 September 2011. When I mentioned the incident, he said that during his visits to the town he heard that Haafuun was once bombarded and reduced to the "heap of ruins." He recalls that shipwreck incidents were still frequent in the area during his tenure when he was serving the military regime in the early 1970s. At that time "the military regime was to take the properties found on the shipwreck."

74 Charles J. Cruttenden, "Memoir on the Western or Edoor Tribes, Inhabiting the Somali Coast of N.E. Africa, with the Southern Branches of the Family of Darrood, Resident on the Banks of the Webbe Shabeyli, Commonly Called the River Webbe," Journal of The Royal Geographical Society of London vol. 19 (1849), p.74. Cruttenden was in charge of commerce with the Somali territories.

75 Durrill, “Atrocious Misery," p.287.

76 Brouwer, "Non-Western Shipping Movements," p.24. 
among the coastal clans as the booty empowered certain sub-clans at the expense of others. ${ }^{77}$ The anarchy spread when inland clans became envious of the increasing prosperity of the coast, giving rise to assassinations and counter-assassinations.

In 1837, a local clan chief, who made himself a petite-warlord, was murdered because he monopolised pirate plundering. Those who killed him "hoped [with] the assassination to regain control over the loot from shipwrecks." ${ }^{78}$ The situation soon worsened and seemed to be out of hand, degenerating into an open war, when the British Memmon wrecked on the coast near Cape Guardafui on 1 August 1842. Rival local clans "dispatched their men to loot the ship" and "they did not share the booty with the residents of nearby Bandar Murayah" village. Ferocious fighting took place after local clan chiefs were blamed by other rival clans for "daring to appropriate to themselves property cast on the shore by the sea, without the consent" of the others. The dispute over pillage became more intense when British officials in Aden sent emissaries to intervene with one clan chief over another. In the words of Cruttenden; "I was employed at the wreck of the East India Company's steam-frigate Memnon, at Ras Assair, on the N.E. coast of Africa ... I employed myself in obtaining what information I could, relative to the tribes on the coast, which I had the honour to forward to Government." 79 Hanley's observation drives home the intensity of the struggle among the clans:

I never saw a Somali who showed any fear of death, which, impressive though it sounds, carries within it the chill of pitilessness and ferocity as well. If you have no fear of death you have none for anybody else's death either, but that fearlessness has always been essential to the Somalis who have had to try and survive hunger, disease and thirst while prepared to fight and die against their enemies, their fellow Somalis for pleasure in the blood feud. ${ }^{80}$

Charles Graves, an American officer in the Egyptian army visiting the area, observed that one of the local clans was "nearly exterminated" in fighting for shipwreck spoils. Prior to these incidents, pirate activities were dominated by certain clans who had "exclusive control over shipwrecks," ${ }^{81}$ but the Memmon and other subsequent pillaging of shipwrecks by other clans revolutionised Puntland piracy, and broke the earlier "monopoly over booty and patronage." Pillaging created a deadly competition for power and profit as clans grappled for access to piracy. In the words of one traveller, the clans seemed "constantly at war" with each other. Charles Guillain, a French government agent, observed that clan chiefs were involved in "pacifying a tribe in revolt." 82 The subsequent internecine clan war triggered by the wreck of a French steamer named

77 See Durrill, “Atrocious Misery,” p.289; and Murphy, Somalia: The New Barbary?, p.2.

78 Durrill, “Atrocious Misery,” pp.294-99.

79 Cruttenden, "Memoir on the Western or Edoor Tribes," p.49.

80 Hanley, Warriors: Life and Death, p.29. Hanley personally pacified some devastating Somali clan feuds in which he had observed that "two hundred and sixty-three men, women and children had been speared, stabbed, hacked to death and those of the women who escaped, left to die of thirst in the bush' (p.46).

81 Durrill, “Atrocious Misery,” pp.294-304.

82 Guillain, Documents sur l'histoire, p.397, quoted in Durrill, “Atrocious Misery,” p.300. 
Mekong precipitated the degree of booty contestation between the warring clans. Hess has shown that the Puntland "region was undergoing a period of internal strife. For several generations the sultans of the Mijjertein [local clan] had monopolized all maritime trade and run a well-organized industry of salvage operations for the many ships that went aground on the treacherous coast of Cape Guardafui." ${ }^{83}$

One major development was the British occupation of Eden city of Yemen ${ }^{84}$ - the most important port in Arab Peninsula - and establishment of a coaling station there in January 1839. ${ }^{85}$ The Aden officials, under the direction of British India, were responsible for the British interests in the Somali coast, and endeavoured to protect wrecked crews from pirates' brutality. The British representatives agreed to pay the local clan chief an annual salary of 360 Maria Theresa dollars. ${ }^{86}$ This was in effect a bribe for the protection of survivors of shipwrecks, that allowed pillaging of shipwrecks to continue and thus did nothing to stop classical onshore piracy.

Kapteijns and Spaulding relate a further effort to deal with continued violence and instability nearly forty years later:

The British, after a series of ad hoc arrangements with the Majerteen, decided to seek to negotiate a formal Anglo-Majerteen agreement in December 1878 when the steamer Voltigem was wrecked in bad weather off Alula. That part of the coast was under the authority of Yusuf Ali, whom the British considered to be "a cousin and feudatory [vassal] of Sultan Uthman." The Somali plundered the cargo of the Voltigem after having fought off, they claimed, no less than thirty-four pearl-fishing vessels from Sur. As Yusuf Ali himself told the British, "The Somalis also plundered a number of guns and some ammunition, but I did not prevent them, there being famine in the country. I could have been able to recover from them (the Somalis) all that they plundered, but they were in a starving condition." "It is our custom," he added, "when any vessel is wrecked on our coast, we take for ourselves all that the vessel contains and do not wait for an answer from Aden. I have sold the shipwreck..." Having little choice but to put a good face to the situation, the British Resident concluded: "The action taken by the Alulah Chief is that of an uncivilized ruler, and cannot be gauged [sic] by any civilized law, and hence any parallel in justice cannot be drawn. Superior force alone can be admitted as constituting right, and such reply to the Chief would be a simple solution to the difficulty, but I do not consider it politic, viewing the liability of future disasters on

83 Hess, Italian Colonialism in Somalia, p.8.

84 See Gavin, Aden under British Rule, p.91. For British maritime history, see Gerald Graham, Great Britain in the Indian Ocean: A Study of Maritime Enterprise, 1810-1850 (New York: Oxford University Press, 1967); and T. E. Marston, Britain's Imperial Role in the Red Sea Area 1800-1878 (Hamden, Connecticut: Shoe String Press). The British garrison at Aden was initially "dependent on the Somali coast for food supplies than those that were on the Arabian hinterland." See Leila Ingrams and Richard Pankhurst, "Somali Migration to Aden from the $19^{\text {th }}$ to the $21^{\text {st }}$ Centuries," African and Asian Studies vol. 5, nos. 3-4 (2006), p.374.

See Col. E. A. Stanton, "Secret Letters From The Khedive Ismail in Connection with an Occupation of the East Coast of Africa," Journal of the Royal African Society vol. 34, no. 136 (1935), pp.269-82. 
the Mijjerteyn Coast, to meet the present claim in this spirit." ${ }^{, 87}$

The war for pirate booty, together with the scarcity of water and shortage of food stuffs, which were omnipresent in Puntland, helped precipitate famine after famine; the worst occurred in 1843 and 1884. In 1872, local clan chiefs told Samuel Miles, a British officer who visited them, that a large portion of their inhabitants "died of starvation." Miles observed that the villagers appeared "miserably poor" and "the universal drought in the country had visited this place." 88 Some residents were "reduced to eating grass and seeds from trees," while a "dozen emaciated women huddled around a fire cooking a pot of leaves for their meal,", with their children nearby chewing "ravenously at a branch cut from a bush." ${ }^{\prime 89}$ Even though food stuffs from the pirate booty brought some relief, the extreme weather conditions and unforgiving environment forced locals to return to camel rustling and raid one another "for the little food that was left." Durrill relates:

Herders began to raid one another for the little food that was left. The Iise Mahamuud [a local sub-clan] pillaged the Ismaan Mahamuud [another local subclan]. The Ismaan Mahamuud in turn robbed Dhulbahante [a neighbouring Harti clan] [...] In December 1880, war broke out. Dhulbahante warriors invaded the Dharor Valley and threatened to attack Bander Gassim [Boosaaso]. Residents there reportedly went about their business armed and on "continual alert." Whether that attack came we do not know, but the Dhulbahante were in retreat by January 1881 . The Warsangeli [another neighbouring Harti clan] had attacked them from the north. The Iise Mahamuud to the south, meanwhile, had regained control of the Dharor Valley. ${ }^{90}$

Cruttenden reported that Haafuun, "like the whole Somali coast was suffering from long-continued drought, which had occasioned much misery amongst them." $" 91$

While classical pirate acts were the cause for perpetual war in Puntland, the origins of the famine emanated from the local clan leader's "hasty commitment to capitalism," which resembled a "political economy at war with itself." 92 As locals had no understanding of capitalism per se, Lidwien Kapteijns claims that it was born with the British colonialism, contending that the "alterations in the way in which pastoral society was linked to the outside world gradually began to first transform and then undermine that society." 93 As she explains:

87 Kapteijns and Spaulding, "From Slaves to Coolies," pp.2-3.

88 Samuel Barrett Miles, "On the Neighbourhood of Bunder Marayah," Journal of the Royal Geographical Society vol. 42 (1872) quoted in Durrill, "Atrocious Misery,” p.302.

89 George Revoil, La Vallee du Darror (Paris, 1882), pp.94-351, cited in Durrill, "Atrocious Misery," p.304.

$90 \quad$ Ibid., p.304.

91 Cruttenden, "Memoir on the Western or Edoor Tribes," p.75.

92 Durrill, “Atrocious Misery,” p.306.

93 Lidwien Kapteijns, "Gender Relations and the Transformation of the Northern Somali Pastoral Tradition," International Journal of African Historical Studies vol. 28, no. 2 (1995), p.252. 
there was another road that led to the acquisition of wealth and power by individual men, a short-cut that created opportunities for quick individual advancement and could dramatically change the fortunes of the groups involved: this consisted of raiding and warfare. Young men who were not yet socially and economically established (often unmarried men) could, under the leadership of a charismatic and fearless entrepreneur/leader (the abbaanduule) decide to intensify their labor efforts and make an ambitious bid for quick wealth through raiding or warfare. ${ }^{94}$

Warfare between two ambitious clan chiefs, Osman Mohamud and Yusuf Ali intensified when the latter exported plunder for cash rather than distributing it among the population. As Durrill noted, "Yusuf Ali and his followers plundered two wrecked steamers at Cape Guardafui without reserving for the sultan his customary share" and decided to send "the scavenged goods directly to Aden for sale." "95 The local tradition dictated that the lion's share should be reserved for the clan chief. Yusuf Ali was accused of breaching a maritime customary law that all shipwreck booty was the sultan's personal property; then the sultan was expected to distribute a considerable amount of the spoils among his clansmen. ${ }^{96}$ Indeed, "Yusuf Ali temporarily disclaimed greater ambitions because Ismaan held his daughter as a pawn. This solution did not last long. In 1883, with Italian support Yusuf Ali organized a sultanate of his own at Hobyo on the south coast below the border." 97

The pirate activities - the ransacking of vessels that wrecked on Somali coastwere one of the factors that induced European powers-Britain, French and Italy-to intervene in that part of Somalia and ultimately invade, to exercise control over the whole Somali coast. The pirate attacks on pearl fishers in the waters of British Socotra ${ }^{98}$ continued until it was temporarily stopped by the Italian bombardment of Boosaaso in 1924 and the subsequent invasion of Hobyo in $1927 .{ }^{99}$ In asserting control over the northern coast, Italy detained two of the most combative clan chiefs in the area, Osman Mohamud and Yusuf Ali. The clan chiefs who replaced them cooperated with the European occupiers. Hanley narrates an exchange he had with a local clan chief in the 1940s:

On the desolate northern coast of Somalia two castaways were once brought to me by an old chief. "Give them a piece of rag each to cover their loins," the old chief said.

94 Ibid., p.248.

95 Durrill, “Atrocious Misery,” pp.303-04.

96 On the other side of the coast in Arabia, customary laws such as this one were somewhat distinctive, yet it seemed similar in some ways. See R. B. Serjeant, " Maritime Customary Law off the Arabian Coasts, " in M. Mollat (ed.), Societies et compagnes de commerce en Orient et dans l'ocean Indien (Beurit/Paris: Actes de Huitieme Colloque International d'Historie Maritime, 1966).

97 Durrill, “Atrocious Misery,” p.305.

98 See Hess, Italian Colonialism in Somalia, pp.127-28.

99 Baldacci noted the bombardment of Bereda, a coastal village, in 1909, by the Italian gunboat Volturno after the clan chiefs refused "to render homage to our nation." See Baldacci, "The Promontory of Cape Guardafui," p.70. 
"They have come out of the sea naked this morning." The two castaways were innocent, hopeful youths with thick hair, their hands over their groins while the swarms of little boys yelled laughing at them. "What happened to you?" I asked these grave, worried youths who sighed with relief when they wrapped the cloth I gave them round their waists. They told me they had stowed away on a British ship at Aden, a ship bound for India, and all had gone well for a day until they were found. They were then thrown over the side, a plank following them into the sea. They floated for two days on that plank in a sea full of huge sharks until they were washed ashore near Bosaso, where I was going slowly round the bend at the time. ${ }^{100}$

\section{Contemporary offshore piracy}

The assertion of Italian control in the late 1920s marked the end of piracy until 1991, with the collapse of the dictatorial Somali military regime that had succeeded European colonial administration. From a historical perspective, the prompt reemergence of piracy with the collapse of central authority has some elements in common with that of the nineteenth century and early twentieth century, save that international interests at stake are not so large as to prompt something like the British solution of bribing clan chiefs of Puntland, or the ultimate Italian response of large scale armed intervention.

Contemporary pirates are former militias of local warlords and pseudo fishermen, but Anderson stresses that they are above all driven by a "determination for needs satisfaction." ${ }^{101}$ Soon after obtaining ransom money, pirates have shown eagerness to marry the most beautiful local girls and drive the best cars.

This excess has created a budding pirate culture. Pirate weddings are elaborate two - or three-day affairs, stretching deep into the night, with bands - and brides - flown in from outside Somalia and convoys of expensive $4 \times 4$ trucks. The prettiest young women in pirate towns dream of a pirate groom; little boys can hardly wait until they are old enough to sling an AK-47 over their shoulder and head out to sea. In these places, the entire local economy revolves around hijacking ships, with hundreds of men, women, and children employed as guards, scouts, cooks, deckhands, mechanics, skiff-builders, accountants, and tea-makers. ${ }^{102}$

Classical pirates similarly sought luxury goods, and through them, social status, but had to await the bounty that the sea brought to them in the form of wrecked ships. In the 1840s pastoralists-turned-scavengers told Cruttenden that they stopped drinking coffee due to lack of income to buy it from Yemen, informing him: "if we drink coffee once, we shall want it again, and where are we to get it from?" ${ }^{103}$ The classical pirates

100 Hanley, Warriors: Life and Death, pp.106-07.

101 Elliot A. Anderson, "It's a Pirates Life for Some: The Development of an Illegal Industry in Response to an Unjust Global Power Dynamic," Indiana Journal of Global Legal Studies vol. 17 (2010), no 2.

102 Gentleman, "The Pirates Are Winning," p.1.

103 Charles J. Cruttenden, "Report on the Mijjertheyn Tribe of Somalis, inhabiting the district forming the North-East point of Africa," Transactions of the Bombay Geographical Society 
lacked the means to go to sea to hunt booty.

By contrast, contemporary pirates take advantage of modern technology, fast motor boats, GPS systems, night vision goggles, and powerful light weapons. In the early January 1991, two weeks before Siad Barre fled from Mogadishu, pirates successfully hijacked the first ship in more than half a century, when they captured the MV Naviluck sailing from Mombasa to Jeddah off Cape Guardafui, killing three of the crew and taking several others on shore. ${ }^{104}$ Seven months later, they attacked MV Valdora, but unsuccessfully.

Violence is a feature of both classical and contemporary piracy, "savage" attacks on shipwreck survivors in earlier times, and, more recently, instances of "systematically torturing hostages, subjecting them to beatings, locking them in freezers and litigating their genitals with plastic ties." ${ }^{105}$ In the nineteenth century, violence was mitigated by British bribery to the local clan chief, and so too contemporary pirates seek ransom for their hostages. Here is an account of one Captain whose wife was among crewmates held for nearly two months after pirates boarded his ship on 1 February 2008.

At about 3pm on Friday 1 February, seventy miles north of Cape [Guardafui], I was alerted by a shout. On our starboard side were five pirates in a six-metre white plastic boat powered by 48hp Yamaha engines. I thrashed the tug to the left, then right, forcing them to sheer away. This cat and mouse game continued until another boat with four more approached. I knew we couldn't avoid them so I stopped our engine. The pirates next attempted to winch their boats to ours but only succeeded in dumping their spare ammunition into the sea ... By late Sunday we arrived in Eyl where 15 more pirates boarded our ship. From then on around twenty were always aboard, including their personal Mullah [local Sheikh] ... One pirate called Ahmed told us he had been in the coastguard, and only Ahmed and one or two others who had also been coastguards understood our engines... The pirates, armed with AK47s, spent every day chewing khat... [One pirate] kept saying "go on—go on" but the anchorage wasn't safe. He hit me across the back of my head. I said we wouldn't go anywhere if he hit me again and he didn't... During the ordeal, I lost weight but was never really hungry. Genuinely, I think they just needed the money. ${ }^{106}$

Another interesting similarity of classical and contemporary piracy is the hiring of a local Sheikh to join in pirate activity. In line with the case of the "mullah" mentioned by the detained captain, classical pirates hired a Sheikh to conduct a meditation prayer for Allah to make "infidel" ships wreck regularly on the coast. An American traveller who visited Puntland in 1878 recorded: "a priest is stationed in the mountains near Cape Guardafui who prays day and night that God will drive Christian vessels ashore that they may plunder them. This was told me by the Chief of Hunda [small village in Puntland]

vol. 7 (1846), p.114.

104 Murphy, Somalia: The New Barbary?, p.12.

105 Katharine Houreld, 'Somali Pirates Torturing Hostages', Associated Press, 20 May 2010, cited in Bahadur, The Pirates of Somalia, p.246.

106 Quoted in Middleton, Pirates and How to Deal With Them, p.7. 
who regarded it as a very prudent, proper and pious precaution- he thinking I was a Muslim." ${ }^{107}$ Unlike in the era of classical piracy, the monsoon season leads to a decrease in contemporary piracy, because heavy weather is a menace to the pirates' small craft.

Contemporary pirates rationalise their actions by echoing the oft-repeated mantra that ship hijackings are inspired not by avarice, but to protect the environment from nuclear toxic waste and save lobster, shrimp, tuna and whitefish from foreign trawlers. In this regard, they seem more concerned with fish than people, because pirates have not spared merchant vessels carrying humanitarian aid to the needy population in the faminestricken areas in southern Somalia. Indeed, they_inadvertently (or perhaps advertently) - contribute to this human catastrophe.

The impetus to piracy, whether classical or contemporary, is to acquire wealth at almost any cost in brutality. Since 1991, the collapse of security institutions has again opened the door to these impulses, impulses inherent in nomadic culture, which strongly sanctions plunder and booty. These impulses may be ameliorated through modern education, to encourage a culture of moral obligation rooted in respect for human rights. Most pirates rarely went to school, even compulsory Koranic schools, in their childhood. Still education is at best a long-term solution. Improved employment and economic opportunities for male youth might be "the most effective way of curbing organised crime." 108

\section{Dealing with Devil's Children}

The Netherlands is the first European government to bring Somali pirates to trial. In once sense this is fitting, for it was the violent acts of piracy committed by the Dutch pirates in the Red Sea in the seventeenth century that discouraged seafarers from setting course for the Somali and Arabian coasts. ${ }^{109}$ In attempting to tackle the failed state syndrome in Somalia, the international community needs to better understand the Somalis and their history, culture, traditions, and way of life. As Hansen observes, there is no single solution to Somali piracy. ${ }^{110}$ Putting an end to what is referred to "the third wave of piracy in Puntland" or to what Santiago Iglesias Baniela calls the "advanced phase" of Somali piracy is perplexing to Somalis and non-Somalis alike. Said Samatar suggests collective punishment would uproot piracy in Puntland. He recommends methods employed by Brigadier R. H. Smith, the officer who led the British Military Administration in Somalia in the aftermath of World War II.

Instead of chasing around uncatchable, elusive pirate speed boats over the vast waters of the Indian Ocean, [the West] should place a spy in all the well-known home bases of these thieves, find out the clans they belong to, arrest their elders and

107 Charles Graves to Chichi Graves, 22 May 1878, Gravers Papers, p.21, cited in Durrill, “Atrocious Misery," p.289.

108 Correspondence with Weinstein, 14 September 2011.

109 Brouwer, "Non-Western Shipping Movements," p.32 and p.14. One may surmise that Qasimi piracy was a counter against Dutch pirates.

110 See Hansen, Piracy in the Greater Gulf, p.62. 
round up their camels. Then the elders should be warned that if ship and crew are not returned safely immediately, they will be taken to a remote island, say Diego Garcia, where they will rot away to the end of their miserable lives... To put a fine point on this: if the elders refuse to comply, the threat of maximum harshness as an object lesson should be carried out. I remain convinced that this would work. But do you, [the West], have a stomach for the disagreeable business of collective punishment based on what happens on the high seas? ${ }^{111}$

The long-term approach which is agreed upon by many stake-holders, including some pirates, is to create a strong, functioning Somali government that does not hide under the belly of the sub-clan quasi states, but imposes a unitary rule over the whole country. A strong Somali state based on social justice, equality and human rights values would be a decisive instrument in the war on piracy. ${ }^{112}$ As it is, the absence of a government capable of shutting down pirate bases and their sources of on-shore support, and "the lack of deep international engagement and proper enforcement of arms control" create a situation in which pirates are "free to grow into a more potent force." 113

Until Somalia revives itself and builds a functioning state, the international community has to empower local civil society groups in order to displace local warlords who have been taking advantage of the pirates' booty to exert authoritarian power. Local civil society groups show willingness to contribute to efforts to reinstitute a Somali state, whereas local warlords currently leading sub-states are disinclined to endorse any government that does not allocate them a lion's share of revenue. It appears reasonable to engage with clan chiefs in areas where pirates enjoy sanctuary, not by bribing the chiefs, but by pressuring them to collaborate in attempts to shut down pirate operations.

Despite the fact that clan consciousness constitutes a parallel religion in the Somali context, approaching local clan chiefs would be more productive in tackling piracy than recognising rapacious warlords. Clan chiefs, though they may be corruptible as warlords, have the authority to impose rules on fellow clansmen that stipulate pirate acts are haram (sinful) and may also influence business people who invest in piracy on the basis of clan affiliation. It has been demonstrated that "pirate gangs do not behave as sheer delinquents; they follow clan rules, they respect the authority of clan elders, and they do not behave as thugs when they are onshore." 114

Yet Puntland authorities seem unwilling to actively combat pirates. When one Somali was once asked, "What do you want most?" he retorted, "To be well governed, but to be left alone." "115 Unlike classical pirates, contemporary pirates appear not to have

111 Said S. Samatar, “An open letter to Uncle Sam: America, pray leave Somalia to its," Journal of Contemporary African Studies vol. 28, no. 3 (2010), p.320.

112 In using social justice, we follow Amartya Sen, The Idea of Justice (Cambridge, MA: Harvard University Press, 2009).

113 Nori Katagiri, "Containing the Somali Insurgency: Learning From the British Experience in Somaliland," African Security Review vol. 19, no. 1 (2010), p.42.

114 Marchal, "Somali Piracy: The Local Contexts," p.40.

115 Hanley, Warriors: Life and Death, p.75. 
political ambitions which might otherwise trigger crackdowns by Puntland authorities and other local warlords. Outside pressure in needed. Roland Marchal, interviewed for this study, insisted that "identification of the business networks" in order to block financial support could be one way to curb piracy. ${ }^{116}$ A more direct, immediate method would be to sanction local sub-state authorities through such measures as travel restrictions and freezing funds received through Somali Hawala (money remittances).

Another alternative is one that the United States and other western states are reluctant to endorse: encouraging Sharia courts inside the clan territories. Islamic Sharia courts could be a useful, vital instrument in combating piracy. The United States Office of Naval Intelligence (ONI) admits that the "threat of strict punishment under Sharia law was likely a significant deterrent to piracy operations off [Somalia]. It stands to reason that the removal of the Islamic militants from influence in this region also removed" this check on piracy. ${ }^{117}$ The Islamic Courts Union (ICU) effectively combated pirates during the brief rule over most of southern Somalia (its authority did not extend to Puntland due to Ethiopian presence). The ICU's record indicates that a functioning government with the support of the Somali public would be capable of eradicating piracy. As noted by Hansen, "Sharia courts were one of the most efficient remedies against piracy." ${ }^{118}$ This supports Hanley's observation that "[o]nly the Somalis can change things, when they want to, which is the way it should be." 119

\section{Conclusion}

This study's brief look at the history of the early Somali piracy has shown that the same socio-economic factors that gave rise to nineteenth century shipwreck plundering led to the resurgence of Somali piracy in recent decades,and still challenge the lives of Puntland residents. Somalis adapted long ago to the "world of camels, waterholes and spearmen under a merciless sun," 120 and much has not changed. Similar to Portenger's description of classical pirates in 1801, Rachel Chandler, a British woman held hostage for more than a year, has described contemporary Somali pirates as the "devil's children." 21 Somali pirates do not accept the label burcad-badeed (sea pirates), let alone devil's children; rather, they prefer such monikers as "Defenders of Somali Territorial Waters," "Ocean Salvation Corps," "National Volunteer Coast Guard," "Somali Marines," "Puntland Coast Guard," and other equally whimsical names. This study has attempted to add historical argument to the existing scholarship on Somali piracy. It has supported John

116 Interview with Marchal, 24 September, 2011.

117 Quoted in Murphy, Somalia: The New Barbary?, p.91.

118 Hansen, Piracy in the Greater Gulf, pp.5-27. For discussions on how Sharia courts combated piracy, see also Baniela, "Piracy at Sea," p.196; and Christopher Jasparro, "Somalia's Piracy Offers Lessons in Global Governance," Yale Global, 6 April 2009, p.2.

119 Hanley, Warriors: Life and Death, p.110.

120 Ibid., p.50.

121 Paul Chandler, Rachel Chandler (with Sarah Edworthy), Hostage: a year at gunpoint with Somali gangsters (Edinburgh: Mainstream, 2011), p.311. See also Colin Freeman, KIDNAPPED: Life as a Somali Pirate Hostage (London: Monday Books). 
Burnett's contention that even more terrorism might occur in Somali waters if a political solution is not found soon. ${ }^{122}$ While literature on contemporary Puntland piracy demonstrates the involvement of the higher echelons of the local authority, in which corruption is pervasive, it neglects to note that this in nothing new: local clan chiefs benefited greatly from nineteenth century shipwrecking plundering.

This study has shown the little noticed but strong continuities between contemporary and classical piracy. Piracy has been pursued above all to gain goods, wealth, and social status, and religious justification is nothing more than a thin veil. Scholarship continues to assert that the re-establishment of a central Somali state is not necessarily a sure remedy for piracy. There is considerable truth in this argument. Until the culture of looting on the part of Somali pastoralists is transformed, piracy will, the historical record suggests, periodically recur. But by denying piracy's "historical background and pursuing an exclusively military strategy, the international community is only repeating a political mistake already made onshore against the terrorist threat: there is no military solution, and policing requires the mid-term vision of a solution for Somalia that no one is yet ready to spell out." ${ }^{123}$ A problem two hundred years old does not disappear within a few years and if unrelenting efforts are not pursued to curtail pirates, they will continue to return to business as usual.

122 John Burnett, “The Next 9/11 Could Happen at Sea," New York Times, 22 February 2005.

123 Marchal, "Somali Piracy: The Local Contexts," p.47. 